\title{
Organ-specific Antibodies in Patients with Lichen Sclerosus
}

\author{
S. K. GOOLAMALI， E. W. BARNES，W. J. IRVINE， SAM SHUSTER
}

British Medical fournal, 1974, 4, 78-79

\section{Summary}

Organ-specific antibodies were looked for in 26 patients with lichen sclerosus. Ten of the 25 female patients $(40 \%)$ had organ-specific antibodies to thyroid cytoplasm and $11(44 \%)$ had organ-specific antibodies to gastric parietal cells. Both values were significantly greater than those obtained in age-matched controls. None of the sera from patients with lichen sclerosus contained antibodies to steroid-producing tissues. No organ-specific antibodies were found in the one male patient.

The findings suggest that lichen sclerosus may be related to an autoimmune process.

\section{Introduction}

During a survey of patients with vitiligo we noticed that two also had lichen sclerosus, and Wallace (1971) had suggested that this association might be significant. As previous studies have shown an increased incidence of organ-specific antibodies in patients with vitiligo (Cunliffe et al., 1968; Bor et al., 1969) we looked for organ-specific antibodies in patients with lichen sclerosus.

\section{Patients and Methods}

Twenty-six patients with lichen sclerosus who were attending a dermatology clinic were studied; 25 were female and 1 was male and their ages ranged from 14 to 70 years (mean $55 \cdot 2$ years). The diagnosis was made clinically and confirmed histologically in the 17 patients in whom a skin biopsy was performed. Control subjects consisted of 443 women who were blood donors and hospital patients not known to have clinical diseases associated with autoimmunity. The age distribution of the female patients with lichen sclerosus and the controls is shown in the chart.

Sera were stored at $-20^{\circ} \mathrm{C}$ in small volumes and tested in batches. All sera were examined for the presence of antibodies to thyroglobulin, thyroid cytoplasm, gastric parietal cells, and intrinsic factor (type I) using techniques previously described (Irvine et al., 1970).

The lichen sclerosus sera were in addition tested for antibodies against steroid-producing tissues-for example, human adrenal cortex, human ovary, placental trophoblasts, and interstitial cells of rabbit testis (Irvine et al., 1969).

Serum vitamin $B_{12}$ was estimated by radioimmunoassay (Britt et. al., 1969).

\footnotetext{
Wellcome Laboratories for Research into Skin Disease, Royal Victoria Infirmary, Newcastle upon Tyne NE1 4LP S. K. GOOLAMALI, M.B., M.R.C.P., Senior Registrar SAM SHUSTER, PH.D., F.R.C.P., Professor

Clinical Immunology Laboratories, University Department of Therapeutics, Royal Infirmary, Edinburgh EH3 9YW

E. W. BARNES, B.SC., M.R.C.P., M.R.C., Clinical Research Fellow W. J. IRVINE, D.SC., F.R.C.P., Consultant Physician
}

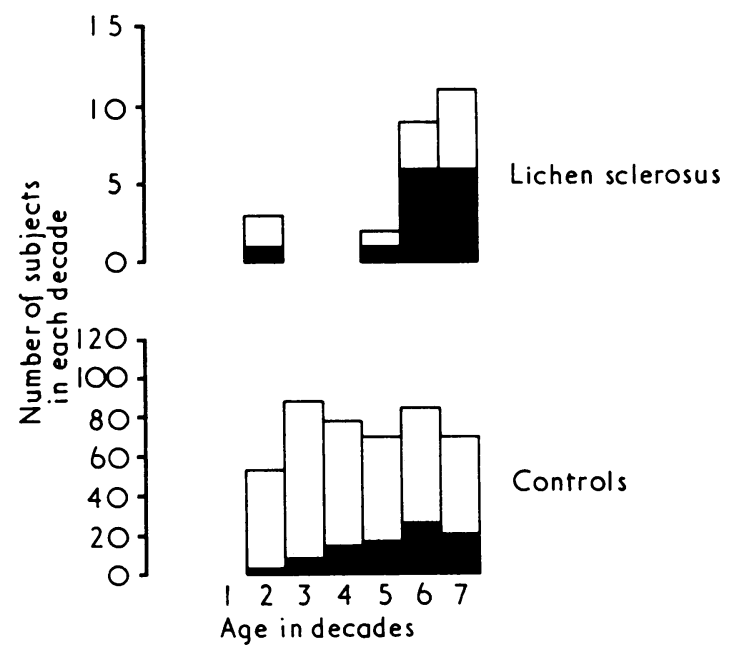

Number of subjects with antibodies to thyroglobulin, thyroid cytoplasm, and or gastric parietal cell cytoplasm among 25 female patients with lichen sclerosus and 443 female controls. Shaded area indicates number positive for antibodies.

\section{Results}

The proportion of female lichen sclerosus patients and controls with autoantibodies is shown in the table. Of the 25 female patients $10(40 \%)$ had organ-specific antibodies against thyroid cytoplasm and $11(44 \%)$ had antibodies against gastric parietal cells (see table). These incidences were significantly increased $P<0.001$ when compared with age-matched controls, and particularly so in patients above the age of 50 years. Organ-specific antibodies were not found in the one male patient.

Proportion of Female Lichen Sclerosus Patients and Control Subjects with Organ-specific Antibodies in Serum

\begin{tabular}{|c|c|c|c|c|}
\hline \multirow{2}{*}{ Antibody } & \multicolumn{2}{|c|}{$\begin{array}{l}\text { Controls } \\
(n=443)\end{array}$} & \multicolumn{2}{|c|}{$\begin{array}{l}\text { Lichen Sclerosus } \\
\text { Patients }(n=25)\end{array}$} \\
\hline & No. & $\%$ & No. & $\%$ \\
\hline $\begin{array}{l}\text { Thyroid cytoplasm } \\
\text { Thyroglobulin } \\
\text { Gastric parietal cell } \\
\text { Intrinsic factor (type I) } \\
\text { Steroid cell* } \\
\text { Antinuclear factor } \\
\text { Mitochondrial }\end{array}$ & $\begin{array}{r}55 \\
46 \\
35 \\
1 \\
\text { N.T. } \\
1 \\
1\end{array}$ & \begin{tabular}{l|}
12 \\
10 \\
8 \\
$0 \cdot 2$ \\
- \\
$0 \cdot 2$ \\
$0 \cdot 2$
\end{tabular} & $\begin{array}{r}10 \\
0 \\
11 \\
2 \\
0 \\
1 \\
0\end{array}$ & $\begin{array}{r}40 \\
0 \\
44 \\
8 \\
0 \\
4 \\
0\end{array}$ \\
\hline
\end{tabular}

* Human adrenal cortex, ovary, placental trophoblasts, and interstitial cells of rabbit testis. N.T. : Not Tested.

More than one antibody was found in nine patients ; two patients with parietal cell antibody also had increased titres of intrinsic factor antibodyat 29.5 and $27.0 \mathrm{U} / \mathrm{ml}$, and seven had both thyroid cytoplasm and gastric parietal cell antibodies. Antinuclear antibody was found in one of the 26 patients.

The presence or absence of these antibodies was not related to the severity or duration of the cutaneous disease. One of the patients with lichen sclerosus had undergone a subtotal thyroidectomy for thyrotoxicosis and one had a nontoxic goitre. The former patient lacked thyroid-specific antibodies whereas the latter patient had antibodies against thyroid 
cytoplasm. Two patients had vitiligo but neither had autoantibodies. None of the other patients had evidence of an autoimmune disorder or other disease known to be associated with an increased prevalence of the various antibodies studied.

The two patients with intrinsic factor antibody had normal haemoglobin $\left(13.6\right.$ and $15 \cdot 1 \mathrm{~g} / 100 \mathrm{ml}$ ) and serum vitamin $B_{12}$ levels $(280$ and $290 \mathrm{pg} / \mathrm{ml})$.

\section{Discussion}

These results indicate a significantly increased prevalence of autoantibodies against thyroid cytoplasm and gastric parietal cells in patients with lichen sclerosus when compared with control subjects. The presence or absence of these antibodies was not related to the severity or duration of the disease, suggesting that these autoantibodies did not arise as a consequence of lichen sclerosus. Though our control subjects were from Edinburgh and the patients with lichen sclerosus from Newcastle a regional difference in the prevalence of autoantibodies is an unlikely explanation, since the large differences found are outside the range previously reported from different centres (Ungar et al., 1968; Irvine et al., 1969; Irvine et al., 1970; Mathews et al., 1973).

Though the observation of two patients with lichen sclerosus and vitiligo led to the present study neither of the two patients with vitiligo had autoantibodies and no further patients with both conditions were found. In fact, the overall prevalence of vitiligo $(2 \cdot 6 \%)$ in lichen sclerosus as reported by Wallace
(1971) is probably not higher than in a normal population (Lerner, 1959).

Of the 10 patients with thyroid cytoplasmic antibodies only one had clinical thyroid disease though the rest may have had subclinical thyroiditis (Goudie et al., 1959). Two patients with parietal cell antibody also had increased titres of intrinsic factor antibody. The serum vitamin $B_{12}$ level in both patients was normal but they must be considered to be at risk of developing malabsorption of vitamin $\mathrm{B}_{12}$ at some time in the future. (Ardeman et al., 1966). These findings make it likely that the incidence of pernicious anaemia will be found to be increased in lichen sclerosus.

The increased prevalence of autoantibodies in lichen sclerosus suggests that the condition may be related to or caused by an autoimmune process.

\section{References}

Ardeman, S., et al. (1966). Quarterly fournal of Medicine, 35, 421. Bor, S., Feiwel, M., and Chanarin, I. (1969). British Fournal of Dermatology, 81, 83 .

Britt, R. P., et al. (1969). British Fournal of Haematology, 16, 457.

Cunliffe, W. J., et al. (1968). British fournal of Dermatology, 80, 135

Goudie, R. B., Anderson, J. R., and Gray, K. G. (1959). Fournal of Pathology and Bacteriology, 77, 389.

Irvine, W. J., Chan, M. W., and Scarth, L. (1969). Clinical and Experimental Immunology, 4, 489.

mental Immunology, 4, 489.
Irvine, W. J., et al. (1970). Lancet, 2, 163.

Lerner, A. B. (1959). Fournal of Investigative Dermatology, 32, 285.

Mathews, J. D., et al. (1973). Lancet, 2, 754

Mathews, J. D., et al. (1973). Lancet, 2,
Ungar, B., et al. (1968). Lancet, 2, 415 .

Wallace, H. J. (1971). Transactions of the St. Fohn's Hospital Dermatological Society, 57, 9.

\title{
Combined T and B Cell Acute Lymphoblastic Leukaemia
}

\author{
D. G. HAEGERT, J. C. CAWLEY, A. KARPAS, A. H. GOLDSTONE
}

British Medical fournal, 1974, 4, 79-82

\section{Summary}

A case of acute lymphoblastic leukaemia in a 17-year-old male is described. The patient had many distinctive features including a vēry high blast cell count, prominent lymphadenopathy and hepatosplenomegaly, thymic mass, and a fulminant clinical course. Immunological studies on the blast cells using a variety of techniques showed the presence of two distinct subpopulations, one having the surface characteristics of thymus-dependent ( $T$ ) lymphoid cells and the other those of bursa-equivalent (B) lymphoid cells. The case therefore represents the first example of a combined $T$ and $B$ cell acute leukaemia.

\section{Introduction}

It is now widely recognized that lymphocytes derived from human bone marrow (B lymphocytes) possess surface immunoglobulin determinants (Pernis et al., 1971; Hallberg et al., 1974), receptors for the Fc portion of fixed IgG (Brain

\footnotetext{
University of Cambridge, Addenbrook's Hospital, Cambridge CB2 $2 Q Q$

D. G. HAEGERT, M.D., F.R.C.P., Research Fellow, Department of Immunology

J. C. CAWLEY, M.B., PH.D., Research Fellow in Haematological Medicine A. KARPAS, PH.D., Assistant Director of Research in Haematological Medicine

A. H. GOLDSTONE, M.A., M.R.C.P., Senior Registrar, Department of Haematology
}

and Marston, 1973; Hallberg et al., 1973), and receptors for bound C3 (Bianco et al., 1970; Michlmayr and Huber, 1970). Thymus-derived lymphocytes (T lymphocytes), on the other hand, have an affinity for non-sensitized sheep red blood cells (Lay et al., 1971; Jondal et al., 1972). These surface markers have been examined by an ever increasing number of investigators in an attempt to characterize human lymphoid neoplasms as diseases of $T$ or $B$ lymphocyte origin. Results of studies of cases of acute lymphoblastic leukaemia (A.L.L.) have been variable. Whereas some studies have failed to show $\mathbf{T}$ or $\mathbf{B}$ markers in A.L.L. lymphoblasts (Lay et al., 1971; Wilson and Nossal, 1971; Shevach et al., 1972; Wybran et al., 1973, others have found a variable number of cases with $\mathrm{T}$ cell markers on the surface of the lymphoblast population (Borella and Sen, 1973; Chin et al., 1973; Kersey et al., 1973; McCaffrey et al., 1973; Seligmann et al., 1973; Belpomme et al., 1974; Catovsky et al., 1974 a).* Cases of A.L.L. of B cell origin have not been described.

We report here a unique case of A.L.L. with two neoplastic populations, one forming sheep red blood cell rosettes and the second expressing surface immunoglobulin determinants.

\section{Case Report}

A 17-year-old man presented with a two-week history of malaise, cervical lymphadenopathy, and a right facial weakness of sudden

*Since the writing of this paper a single example of B cell A.L.L. has been described in an elderly man (Gajl-Peczalska et al., 1974). 